\title{
Prevalence and serotyping of Listeria monocytogenes in Portuguese live bivalve molluscs sampled in various steps along the sanitary control process
}

\author{
Ana Luísa Pinto ${ }^{1,2}$, Paula Teixeira', Fernanda Castilho ${ }^{2}$, Maria Teresa Felício ${ }^{1,3}$, Filomena Pombal $^{2}$ \\ \& Paul A Gibbs ${ }^{1,4}$ \\ ${ }^{1}$ Escola Superior de Biotecnologia, Universidade Católica Portuguesa, Porto, Portugal \\ ${ }^{2}$ Instituto Nacional de Investigação Agrária e das Pescas, IPIMAR-CRIPN, Matosinhos, Portugal \\ ${ }^{3}$ Escola Superior Agrária, Instituto Politécnico de Castelo Branco, Castelo Branco, Portugal \\ ${ }^{4}$ Leatherhead Food International, Leatherhead, Surrey, UK
}

Correspondence: P Teixeira, Escola Superior de Biotecnologia, Universidade Católica Portuguesa, R. Dr. António Bernardino de Almeida, 4200-072 Porto, Portugal. E-mail: paula@esb.ucp.pt

\begin{abstract}
The prevalence and contamination levels of Listeria monocytogenes were investigated in live bivalve molluscs for human consumption, collected in various steps of the commercial and sanitary circuits in the North of Portugal. Samples of different species were collected per lot before and after depuration treatment in two depuration units and further, when placed in retail markets. Listeria monocytogenes was isolated from $4 \%$ of the samples although with very low contamination levels (less than $100 \mathrm{MPNg}^{-1}$ ). None of the environmental (non-depurated) samples were contaminated with the food-borne pathogen. The positive samples involved depurated and commercialized samples from two lots, one in each circuit. Two serotypes ( $1 / 2 \mathrm{a}$ and $3 \mathrm{~b})$ were detected among the isolated strains. This study demonstrated the possibility of occurrence of L. monocytogenes contamination of live bivalve molluscs along the sanitary control circuit, including at the retail market level. As L. monocytogenes grows well at refrigerated temperatures and in high salt matrixes such as seafood its presence in these products should not be overlooked.
\end{abstract}

Keywords: Listeria monocytogenes, prevalence, serotyping, live bivalve molluscs, sanitary control

\section{Introduction}

Listeria monocytogenes is a non-sporing ubiquitous bacterium, Gram-positive facultatively anaerobic rod
(Farber \& Peterkin 1991). The presence of this pathogen in foods, particularly ready-to-eat (RTE) foods, gained public health significance from several outbreaks of listeriosis in North America and Europe. It is known to be particularly hazardous for high-risk groups such as immuno-compromised people, the elderly, pregnant women and neonates, and has a high mortality rate in these individuals of 20-30\% (Farber 1991a). A recent study showed that healthy individuals can also develop milder forms of gastrointestinal illness upon exposure (Dalton, Austin, Sobel, Hayes, Bibb, Graves, Swaminathan, Proctor \& Griffin 1997).

Bivalve molluscs are among the most consumed seafoods in Portugal as in some other countries, preferably in the raw state or lightly cooked. The microbiological quality control of these RTE foods therefore assumes particular importance (Ben Embarek 1994). The main objective of sanitary control, characterized by a set of steps and procedures, is the guarantee of public health protection. The process depends on the production area classification and monitoring, and on purification and certification of the products in depuration centres. While shellfish has not caused any large-scale outbreaks of listeriosis, small outbreaks and sporadic cases have been caused by smoked mussels and raw oysters (Brett, Short \& McLauchlin 1998; Monfort, Minet, Rocourt, Piclet \& Cormier 1998; Plusquellec, Monfort, Piclet \& Rio 1998). The scarcity of relevant data in our country and the need to provide new information about the potential of raw bivalves as a source of $L$. monocytogenes contamination led us 
to carry out this work, performing a limited study on the prevalence of L. monocytogenes in Portuguese live bivalve molluscs, sampled in various steps of the sanitary control circuit. The serovar identity of the isolates was determined as an epidemiological indicator.

\section{Material and methods}

\section{Samples and sites}

A total of 75 live bivalve mollusc samples were collected from January to July 2004 from two production sites, and analysed for L. monocytogenes along the sanitary control process as shown in Fig. 1. Each lot of shellfish species was sampled in three steps of the circuit: production sites, after depuration treatment in two depuration units (DA and DB) and in two retail markets (MA and MB).

The harvesting sites are situated along the North coast of Portugal (from Aveiro to Vila Praia de Âncora). Bivalve samples, including oysters, mussels, clams, cockles and razor shells, of $1 \mathrm{~kg}$ were collected at each sampling site, stored and transported at $6-8{ }^{\circ} \mathrm{C}$ to the laboratory for analysis. Fifteen to 35 individuals according to the species analysed were scrubbed, rinsed with tap water and opened aseptically.

\section{Listeria monocytogenes detection and quantification}

Listeria monocytogenes detection was performed using the MINI-VIDAS-LMO2 test kit (bioMérieux ${ }^{\circledR}$, Marcy L'Etoile, France) following the manufacturer's instructions. This automated qualitative test has obtained AOAC International Official Methods of Analysis approval. The confirmation of positive samples was performed as described in the MINI-VIDASLMO2 protocol, streaking $10 \mu \mathrm{L}$ of the Fraser broth on PALCAM (Merck, Darmstadt, Germany) and Oxford agar plates (Merck) and incubating at $37^{\circ} \mathrm{C}$ for $24 \mathrm{~h}$. Five to 10 typical colonies from each selective agar were picked, purified on tryptic soy agar (Lab M, Bury, UK) with $0.6 \% \mathrm{wv}^{-1}$ yeast extract (Lab M; TSAYE), incubated at $37^{\circ} \mathrm{C}$ for $24 \mathrm{~h}$ and maintained on TSAYE slants at $4^{\circ} \mathrm{C}$. The L. monocytogenes isolates were phenotyped and biochemically characterized by Gram stain, cell and colony morphology, catalase test, tumbling motility by microscopy, the ability to ferment rhamnose $\left(1.0 \% \mathrm{wv}^{-1}\right)$ but not xylose $\left(0.5 \% \mathrm{wv}^{-1}\right)$ or mannitol $\left(0.5 \% \mathrm{wv}^{-1}\right)$, haemolysis on Sheep Blood Agar (Merck) and CAMP test with Staphylococcus aureus (NCTC 25923) and Rhodococcus equi (NCTC 1621). For quantification of L. monocytogenes in the positive samples, the most probable number (MPN) method was used according to Vaz-Velho (2000).

\section{Serotyping}

Listeria monocytogenes serotyping was performed using two methods, i.e. the L. monocytogenes Seiken kit (Denka Seiken, Tokyo, Japan) following the manufacturer's instructions and, multiplex polymerase chain reaction (PCR) according to Doumith, Buchrieser, Glaser, Jacquet and Martin (2004) using the conditions described by the authors.

\section{Results}

Table 1 shows the prevalence of L. monocytogenes detected in the live bivalve molluscs, i.e. $4 \%$ (three of 75 samples).

None of the bivalve molluscs collected at the harvesting sites contained the pathogen. The three positive samples were found only in depurated clams, although of two different species (Venerupis pullastra and Tapes phillipinarum), demonstrating very low contamination levels (less than $100 \mathrm{MPNg}^{-1}$; data not shown). Two lots were involved (one in each circuit), two of the positive samples being from the same lot (circuit A).

The serotypes of L. monocytogenes were also identified. The multiplex PCR assay clusters L. monocyto-

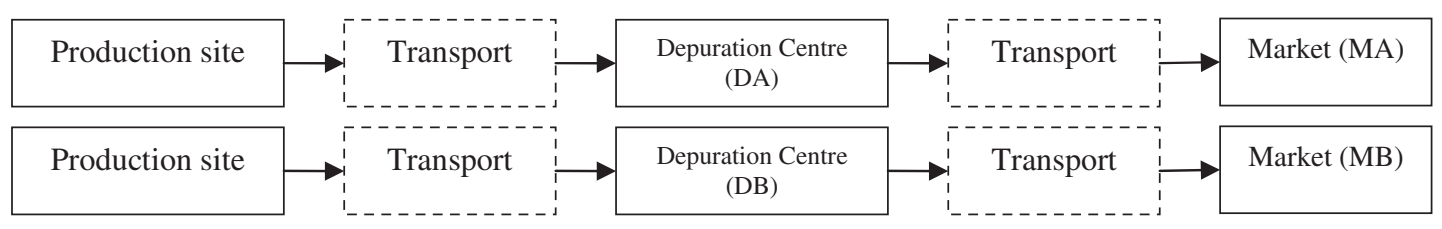

Figure 1 Simplified sanitary control process of live bivalve molluscs (sampling sites are indicated in full boxes). 
Table 1 Listeria monocytogenes prevalence in shellfish

\begin{tabular}{|c|c|c|c|c|c|c|}
\hline \multirow[b]{2}{*}{ Circuit } & \multirow[b]{2}{*}{ Bivalve species } & \multirow[b]{2}{*}{ No. of lots } & \multirow[b]{2}{*}{$\begin{array}{l}\text { No. of } \\
\text { samples }\end{array}$} & \multicolumn{3}{|c|}{$\begin{array}{l}\text { No. of positive samples for } \\
\text { L. monocytogenes }\end{array}$} \\
\hline & & & & $\begin{array}{l}\text { Production } \\
\text { sites }\end{array}$ & $\begin{array}{l}\text { After } \\
\text { depuration }\end{array}$ & Market \\
\hline \multirow[t]{7}{*}{$A$} & Oysters (Crassostrea angulata, Lamarck, 1835) & 1 & 3 & & & \\
\hline & White clam (Spisula solida, L.) & 3 & 9 & & 1 & 1 \\
\hline & Japanese Clam (Tapes phillipinarum, Reeve, 1864) & 1 & 3 & & & \\
\hline & Clam (Venerupis pullastra, Montagu, 1803) & 4 & 12 & & & \\
\hline & Cockle (Cerastoderme edule, L.) & 2 & 6 & & & \\
\hline & Mussel (Mytilus galloprovincialis, Lamarck, 1819) & 1 & 3 & & & \\
\hline & Razor Shell (Solen marginatus, Pulteney, 1799) & 2 & 6 & & & \\
\hline \multirow[t]{8}{*}{ B } & Oysters (Crassostrea angulata, Lamarck, 1835) & 1 & 3 & & & \\
\hline & White clam (Spisula solida, L.) & 2 & 6 & & & \\
\hline & Japanese Clam (Tapes phillipinarum, Reeve, 1864) & 4 & 12 & & & 1 \\
\hline & Clam (Venerupis pullastra, Montagu, 1803) & 2 & 6 & & & \\
\hline & Cockle (Cerastoderme edule, L.) & 1 & 3 & & & \\
\hline & Mussel (Mytilus galloprovincialis, Lamarck, 1819) & 1 & 3 & & & \\
\hline & Razor Shell (Solen marginatus, Pulteney, 1799) & 0 & 0 & & & \\
\hline & Total & 25 & 75 & 0 & 1 & 2 \\
\hline
\end{tabular}

Table 2 Serogrouping of the isolated Listeria monocytogenes strains

\begin{tabular}{|c|c|c|c|c|}
\hline \multirow[b]{2}{*}{$\begin{array}{l}\text { Shellfish } \\
\text { species }\end{array}$} & \multirow[b]{2}{*}{ Circuit } & \multicolumn{3}{|c|}{$\begin{array}{l}\text { L. monocytogenes serotype } \\
\text { group }\end{array}$} \\
\hline & & $\begin{array}{l}\text { Production } \\
\text { site }\end{array}$ & $\begin{array}{l}\text { After } \\
\text { depuration }\end{array}$ & Market \\
\hline Clams & & & & \\
\hline $\begin{array}{l}\text { (Venerupis pullastra) } \\
\text { Clams }\end{array}$ & A & - & $1 / 2 a(3 a)$ & $1 / 2 a(3 a)$ \\
\hline (Tapes phillipinarum) & $\mathrm{B}$ & - & - & $3 b$ \\
\hline
\end{tabular}

genes strains into four major groups (group 1: serotypes 1/2a, 3a; group 2:1/2b, 3b, 7; group 3:1/2c, 3c; and group 4: 4b, 4d, 4e; Doumith et al. 2004). Owing to the inability to serotype the two positive isolates from the circuit A by conventional serotyping, the authors used the multiplex PCR (Doumith et al. 2004). The two strains isolated in sanitary circuit A belonged to the serotype group 1, i.e. 1/2a (3a) identified by multiplex PCR and, the strain from circuit B belonged to the serotype group 2, i.e. $1 / 2 \mathrm{~b}(3 \mathrm{~b})$. In this case, as it was possible to use the Seiken kit, the serotype 3 b was confirmed (Table 2 ).

\section{Discussion}

Compared with other food products, very few studies have been carried out on the prevalence and growth of L. monocytogenes in shellfish. The limited sampling of bivalves along the circuit accomplished in this study demonstrated that these RTE seafoods could be contaminated with $L$. monocytogenes, including at the retail market level. In previous studies conducted in Portugal, Pedro (1996) isolated Listeria spp. and L. monocytogenes in $23 \%$ and $20 \%$, respectively, from 35 shellfish samples; Pereira, Guerra and Bernardo (2001) found L. monocytogenes in $13.1 \%$ of 61 shellfish samples; and Mena, Almeida, Carneiro, Teixeira, Hogg and Gibbs (2004) did not find any shellfish contaminated with the pathogen. Other studies cited in the literature indicate some similar prevalences: Weagant, Sado, Colburn, Torkelson, Stanley, Krane, Shields and Thayer (1988), Buchanan, Stahl, Bencivengo and Corral (1989), Motes (1991) and Jeyasekaran, Karunasagar and Karunasagar (1996) did not find Listeria spp. including L. monocytogenes in shellfish; Colburn, Kaysner, Abeyta and Wekell (1990) found Listeria spp. with frequencies of $1-5 \%$; De Simón, Tarragó and Ferrer (1992) detected L. monocytogenes in $7.5 \%$ (three of 40 ) of the bivalve samples collected at markets and Monfort et al. (1998) obtained a higher prevalence of L. monocytogenes in live shellfish of $11.2 \%$. In general, the levels per gram of the organism in fish products (with the exception of cold-smoked salmon) appear to be lower than $10^{2}-$ $10^{3} \mathrm{CFU} \mathrm{g}^{-1}$ (Farber 1991b). Nevertheless, it is important to take into account that shellfish have been implicated in listeriosis outbreaks (e.g. Monfort et al. 1998). 
The inability to serotype the positive isolates from the circuit A by conventional serotyping led the authors to use the multiplex PCR (Doumith et al. 2004). In fact, Graves, DeWitt, Mauro, Bordoni and Swaminathan (2005) observed agreement between multiplex PCR and conventional serotyping methods of $94 \%$ and suggested multiplex PCR as an alternative method for untypable strains by conventional methods. Cordano and Rocourt (2001) as well as Graves et al. (2005) also found strains untypable by conventional serotyping.

Brett et al. (1998) and Inoue, Nakama, Arai, Kokubo, Maruyama, Saito, Yoshida, Terao, Yamamoto and Kumagai (2000) found the same serovars in bivalve shellfish, whereas De Simón et al. (1992) found serovars $1 / 2 \mathrm{c}$ and $4 \mathrm{~b}$ in bivalve market samples. Most human listeriosis cases ( $>95 \%$ ) are caused by strains belonging to serotypes $1 / 2 \mathrm{a}, 1 / 2 \mathrm{~b}$ and $4 \mathrm{~b}$ (Farber \& Peterkin 1991); however, other factors influence the occurrence of listeriosis.

More information dealing with L. monocytogenes contamination in bivalve molluscs should be collected. Many questions are still unanswered. It appears important to understand the behaviour of Listeria spp. including L. monocytogenes in aquatic environments, the role of depuration in pathogen reduction/elimination, its relationship with faecal indicators, the ecology of the organism in the shellfishprocessing environment, seasonal variations, etc. Moreover, as a psychrotrophic bacterium, L. monocytogenes can grow at low temperatures and, under conditions of high salt content (Handa, Kimura, Takahashi, Koda, Hisa \& Fujii 2005). Thus, refrigerated storage, placement in ice or water used to cool shellfish in markets, among other factors such as transport and handling, could contribute to the introduction and persistence of the organism in the sanitary control and commercial circuits.

In conclusion, this study demonstrated the presence of L. monocytogenes in depurated and commercialized live bivalve molluscs in Portuguese markets. Given the low levels of the pathogen in the analysed samples and their relatively short shelf-life (rarely consumed after 1 week of refrigerated storage), unless these shellfish are temperature abused, L. monocytogenes-contaminated bivalve molluscs should not represent a serious health hazard. Nevertheless, the need for consumer education in Portugal, regarding safe food-handling practices with respect to Listeria spp. contamination, is evident (Azevedo, Regalo, Mena, Almeida, Carneiro, Teixeira, Hogg \& Gibbs 2005).

\section{Acknowledgments}

The authors gratefully acknowledge S. A. Sanamar, L. da Zacarias and L. da Âncoramar for supplying shellfish samples. Financial support for authors A. L. Pinto and M. T. Felício was provided by $\mathrm{PhD}$ fellowships issued by Fundação para a Ciência e a Tecnologia (SFRH/BD/8805/2002) and PRODEP III respectively. This study was co-financed by the European Found (PROGRAMA MARE).

\section{References}

Azevedo I., Regalo M., Mena C., Almeida G., Carneiro L., Teixeira P., Hogg T. \& Gibbs P.A. (2005) Incidence of Listeria spp. in domestic refrigerators in Portugal. Food Control 16, 121-124.

Ben Embarek P.K. (1994) Presence, detection and growth of Listeria monocytogenes in seafoods: a review. International Journal of Applied Bacteriology 68, 189-198.

Brett M.S.Y., Short P. \& McLauchlin J. (1998) A small outbreak of listeriosis associated with smoked mussels. International Journal of Food Microbiology 43, 223-229.

Buchanan R.L., Stahl H.G., Bencivengo M.M. \& Corral F.D. (1989) Comparison of lithium chloride-phenylethanolmoxalactam and modified Vogel Johnson agars for detection of Listeria spp. in retail-level meats, poultry and seafood. Applied and Environmental Microbiology 52, 59-63.

Colburn K.G., Kaysner C.A., Abeyta C. \& Wekell M.M. (1990) Listeria species in a California coast estuarine environment. Applied and Environmental Microbiology 56, 20072011.

Cordano A.M. \& Rocourt J. (2001) Occurrence of Listeria monocytogenes in food in Chile. International Journal of Food Microbiology 70, 175-178.

Dalton C.B., Austin C.C., Sobel J., Hayes P.S., BibbW.F., Graves L.M., Swaminathan B., Proctor M.E. \& Griffin P.M. (1997) An outbreak of gastroenteritis and fever due to Listeria monocytogenes milk. The New England Journal of Medicine 336, 100-106.

De Simón M., Tarragó C. \& Ferrer M.D. (1992) Incidence of Listeria monocytogenes in fresh foods in Barcelona (Spain). International Journal of Food Microbiology 16, 153-156.

Doumith M., Buchrieser C., Glaser P., Jacquet C. \& Martin P. (2004) Differentiation of the major Listeria monocytogenes serovars by multiplex PCR. Journal of Clinical Microbiology 42, 3819-3822.

Farber J.M. (1991a) Listeria monocytogenes. Journal of Association of Official Analytical Chemists 74, 701-704.

Farber J.M. (1991b) Listeria monocytogenes in fish products. Journal of Food Protection 54, 922-934.

Farber J.M. \& Peterkin P.I. (1991) Listeria monocytogenes a foodborne pathogen. Microbiology Reviews 55, 476-511.

Graves L., DeWittW., Mauro L., Bordoni P. \& Swaminathan B. (2005) Comparison of a multiplex PCR assay and conventional serotyping for sero-classification of Listeria mono- 
cytogenes isolates. In: 9 th Annual PulseNet Update Meeting, 9-11 May 2005, Seattle, WA, USA. http://www.cdc.gov/ pulsenet/events_pages/pn_update_2005.htm

Handa S., Kimura B.,Takahashi H., Koda T., Hisa K. \& Fujii T. (2005) Incidence of Listeria monocytogenes in raw seafood products in Japanese retail stores. Journal of Food Protection 65, 411-415.

Inoue S., Nakama A., Arai Y., KokuboY., Maruyama T., Saito A., Yoshida T., Terao M., Yamamoto S. \& Kumagai S. (2000) Prevalence and contamination levels of Listeria monocytogenes in retail food in Japan. International Journal of Food Microbiology 59, 73-77.

Jeyasekaran G., Karunasagar I. \& Karunasagar I. (1996) Incidence of Listeria spp. in tropical fish. International Journal of Food Microbiology 31, 333-340.

Mena C., Almeida G., Carneiro L.,Teixeira P., Hogg T. \& Gibbs P.A. (2004) Incidence of Listeria monocytogenes in different food products commercialized in Portugal. Food Microbiology 21, 213-216.

Monfort P., Minet J., Rocourt J., Piclet G. \& Cormier M. (1998) Incidence of Listeria spp. in Breton live shellfish. Letters of Applied Microbiology 26, 205-208.
Motes M.L. (1991) Incidence of Listeria spp. in shrimp, oysters, and estuarine waters. Journal of Food Protection 54, 170-173.

Pedro S. (1996) Occurrence of Listeria in seafood and its ecoresistence in aquatic environment. Thesis submitted to the Universidade Técnica de Lisboa to attain the degree of Master in Food Science and Technology, 123pp.

Pereira F., Guerra M.M. \& Bernardo F.A. (2001) Natural occurrence of Vibrio spp. and Listeria monocytogenes in bivalve molluscan in Portugal. Journal of Shellfish Research 20, 1229-1233.

Plusquellec A., Monfort P., Piclet G. \& Rio L. (1998) Listeria innocua and Salmonella panama in mussels: a comparative study. Journal of Food Protection 61, 1137-1142.

Vaz-Velho M.M. (2000) Cold-Smoked Fish-Processing and Safety. PhD thesis in Biotechnology, Food Science and Engineering, Universidade Catolica Portuguesa, Portugal, 382pp.

Weagant S.D., Sado P.N., Colburn K.G., Torkelson J.D., Stanley M.H., Krane S.C., Shields S.C. \& Thayer C.F. (1988) The incidence of Listeria species in frozen seafood products. Journal of Food Protection 51, 655-657. 